(C) 2016. This manuscript version is made available under the CC-BY-NC-ND 4.0 license

\title{
Knowledge Spillovers in the Supply Chain: Evidence from the High Tech Sectors
}

\author{
Olov H.D. Isaksson ${ }^{\text {ac* }} \quad$ Markus Simeth ${ }^{\mathrm{b}} \quad$ Ralf W. Seifert ${ }^{\mathrm{cd}}$

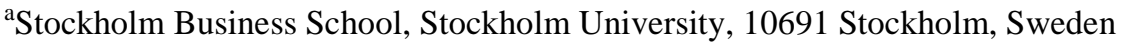 \\ ${ }^{b}$ Universidad Carlos III de Madrid, Department of Business Administration, Spain \\ ${ }^{c}$ Ecole Polytechnique Fédérale de Lausanne, College of Management, Switzerland \\ ${ }^{\mathrm{d}}$ IMD, Chemin de Bellerive 2, P.O Box 915, 1001 Lausanne, Switzerland \\ *Corresponding author. Tel. +4686747207. Email: olov.isaksson@sbs.su.se
}

Research Policy 45 (3), pp. 699-706

http://dx.doi.org/10.1016/j.respol.2015.12.007

\begin{abstract}
In addition to internal R\&D, external knowledge is widely considered as an essential lever for innovative performance. This paper analyzes knowledge spillovers in supply chain networks. Specifically, we investigate how supplier innovation is impacted by buyer innovation. Financial accounting data is combined with supply chain relationship data and patent data for U.S. firms in high tech industries. Our econometric analysis shows that buyer innovation has a positive and significant impact on supplier innovation. We find that the duration of the buyer-supplier relationship positively moderates this effect, but that the technological proximity between the two firms does not have a significant effect on spillovers.
\end{abstract}

Keywords: knowledge spillovers, innovation, buyer-supplier relationship, high tech sectors 


\section{Introduction}

Innovation has long been regarded as playing a key role in the competitive advantage and survival of firms (Audretsch, 1995; Cefis and Marsili, 2006; Schumpeter, 1942). To innovate, firms can invest in internal R\&D or leverage external sources of knowledge. Such external knowledge can be exchanged via spillovers, collaborations, or direct market transactions such as technology licensing. Because of the complexity, uncertainty, and costs of the innovation process, firms are increasingly actively searching for external knowledge that is complementary to in-house R\&D activities (Cohen et al., 2002; Chesbrough, 2003). With regard to particular sources, firms can benefit from the innovative activities of competing firms, academic institutions, and supply chain partners. Correspondingly, survey evidence suggests that downstream partners are an important information source for innovation (Cohen et al., 2002; Belderbos et al., 2004).

In response to the practical importance of external knowledge and downstream partners in firm innovation, various streams of the management and applied economics literature provide related insights. A comprehensive body of studies has quantified the impact of inter-firm knowledge spillovers on firm innovation, traditionally focusing on unintentional knowledge transfers between rival firms (Jaffe 1986; Bloom et al. 2013). Similarly, research on multinational firms and foreign direct investment has examined technology and productivity spillovers from foreign investors to local firms (Almeida, 1996; Görg and Strobl, 2001; Javorcik, 2004). Also, a distinct body of studies has investigated the role of downstream users as a valuable source in firms' innovation processes (von Hippel, 1976; Chatterji and Fabrizio, 2012). Finally, the operations management literature has explored how new product development can be improved by leveraging supplier innovation through integration and collaboration (Primo and Amundson, 2002; Azadegan and Dooley, 2010).

Despite the abovementioned research on knowledge spillovers, external sources of knowledge, and supply chain relationships, we propose that combining several perspectives in one study offers new and valuable insights. In particular, our study investigates (i) the impact of buyer innovation on supplier innovation with a focus on (ii) technological innovation as reflected by patents (iii) using a quantitative empirical design with information on direct linkages between suppliers and buyers. Besides documenting the prevalence and magnitude of knowledge spillovers, we also provide insights into drivers of heterogeneity across firms. One specific characteristic of a buyer-supplier relationship is the typically high frequency of interactions between the companies, which may increase spillovers over time. Thus, we consider relationship duration as a moderating determinant for the impact of buyer innovation on supplier innovation. Furthermore, the role of technological proximity as a moderating factor may differ in the supply chain context compared with that of competing firms.

Knowledge spillovers are often referred to as informal, unintentional and uncompensated transfers of knowledge. However, the innovation literature also routinely speaks of voluntary, intentional 
knowledge spillovers (De Jong and von Hippel, 2009) and strategic spillovers (Harhoff, 1996). In this paper we do not attempt to distinguish between intentional and unintentional knowledge spillovers and adopt a broader definition encompassing both. The empirical analysis relies on firm-level information for publicly traded American firms in high-technology sectors between 1990 and 2006. This information is combined with data on buyer-supplier linkages which is disclosed due to a financial accounting standard. Innovative output is proxied by patent data, which is extracted from the World Statistical Patent database (Patstat). Our sample contains 706 supplier-year observations, with at least one observed buying firm per supplier.

By observing direct linkages between supply chain partners we document a positive effect of buyer innovation on supplier innovation. This result suggests that spillovers are also relevant in the context of supply-chain relationships and therefore complements findings about the positive impact of external knowledge on firms' inventive performance in studies on R\&D spillovers and open innovation. However, the relationship is largely conditional on the duration of the buyer-supplier relationship since, interestingly, there is no evidence of spillovers in newly formed supply chain partnerships. This has novel and interesting implications for both research and practice. Moreover, we find no evidence that knowledge spillovers increase with technological proximity between the supplying and buying firms, which is unexpected since proximity is typically associated with positive benefits for learning (see Orlando 2004).

The remainder of this paper is structured as follows: Section 2 provides a review of the most relevant literature. In Section 3, the hypotheses are developed. In Section 4, the research methodology and data are presented. The econometric results are presented and discussed in Section 5. Robustness tests and post-hoc analysis are shown in Section 6. We conclude in Section 7.

\section{Literature review}

The impact of external knowledge on firm innovation in general, and knowledge flows between supply chain partners in particular, has received considerable attention from several streams of academic literature. The most relevant literature for our study originates from the research areas of R\&D spillovers (including related studies on spillovers from firms' foreign direct investment), open and user innovation, and operations management.

It has been shown that knowledge spillovers lead to an increase in companies' R\&D investments and higher innovation output and productivity (Jaffe et al., 1993; Cohen and Levinthal, 1989; Bloom et al., 2013). The impact of knowledge spillovers on firms' innovation productivity is amplified by technological (Orlando, 2004) and spatial proximity between a firm and its competitors (Jaffe et al., 1993; Lychagin et al., 2010; Mairesse and Mulkay, 2008; Aldieri and Cincera, 2009). Using plant-level 
data, Ikeuchi et al. (2015) find that flows of technological knowledge originating from buyers increase the total factor productivity of suppliers.

Related to geographic proximity, studies on foreign direct investments, international business, and $R \& D$ offshoring explain firms' location choices in order to benefit from productivity and knowledge spillovers from proximate firms (e.g. Shaver and Flyer, 2000; Alcacer and Chung, 2007). The majority of the empirical studies suggest, directly or indirectly, that the buyer-supplier relationship is an important channel through which productivity spillovers occur. Local productivity improvements are considered to be a sign of learning from foreign investors (Almeida, 1996; Görg and Strobl, 2001; Havranek and Irsova, 2011; Javorcik, 2004; Meyer and Sinani, 2009) and trade (Antràs and Helpman, 2004; Saliola and Zanfei, 2009; Sturgeon et al., 2008). Although these studies indirectly point to business transactions as important enablers for knowledge transfer, they cannot observe direct supply chain linkages between firms.

The importance of leveraging external knowledge sources is highlighted by studies on open innovation (Chesbrough, 2003; Laursen and Salter, 2006; Dahlander and Gann, 2010) and user innovation (von Hippel, 1976; De Jong and von Hippel, 2009). Numerous case studies illustrate external knowledge as a crucial input for firms' inventive activities. Specifically with regard to users, the most prominent examples are open source software development and the medical instruments sector. User developers contribute actively to the creation of new software, and clinicians co-develop new surgery tools jointly with companies (e.g. von Hippel et al., 1999; von Hippel and von Krogh, 2003; Jeppesen and Frederiksen, 2006). Because of the difficulties of obtaining large-scale data on firms' interactions with users, the majority of studies rely on qualitative information, with some notable exceptions.

Using data from the community innovation survey (CIS), Laursen and Salter (2006) show that firms that access a broader range of external knowledge sources (e.g. universities, competitors, and customers) and use them more deeply increase their innovation productivity. Belderbos et al. (2004) document that, among other partners, spillovers from customers (including both firm and end customers) may facilitate the creation of radical innovation. With a focus on user innovation, Chatterji and Fabrizio (2012) show that medical instrument firms can improve their patent productivity by interacting with clinicians. ${ }^{1}$ While the user innovation literature acknowledges companies as a user group (intermediate users), the main focus is on the end users of the products and equipment providers, limiting the generalizability of the findings with regard to spillovers of technological knowledge in a supply chain context.

In the operations management literature, the supply chain is a common level of analysis. The effect of supplier involvement in new product development, with focus on project-related outcome dimensions such as project development times, project costs, product quality, and team effectiveness, has been

\footnotetext{
${ }^{1}$ Clinicians are an ambiguous user group, since the leading clinicians in university hospitals can also be regarded as university researchers.
} 
investigated by conducting case studies and surveys (Primo and Amundson, 2002; Appleyard, 2003; Petersen, et al. 2005; Azadegan and Dooley, 2010). The majority of studies suggest that supplier involvement and collaboration has a positive impact on new product development. However, this line of research has little emphasis on technological innovations and R\&D.

\section{Technological spillovers in supply chains}

\subsection{Buying firms as a source of valuable knowledge for innovation}

Firms increasingly leverage external sources of knowledge because of the complexity and costs of the innovation process (Laursen and Salter, 2006). Compared with "traditional" horizontal R\&D spillovers between rival firms, transactions between a buyer and a supplier can act as an additional channel for knowledge diffusion, whereby interactions at the individual level may facilitate the transfer of tacit knowledge (Feldman, 1999; Cassiman and Veugelers, 2001; Cowan et al., 2000). In a supply chain setting, incentives to share knowledge are also greater because of a certain mutual dependence and reduced product-market competition. One would hence expect the innovative output of a firm to be positively influenced by the innovativeness of its buyers. Conversely, in high-technology sectors, it is not obvious that buyers are a particularly relevant source of information, given that these firms draw heavily on academic knowledge and have extensive formal and informal research links to academic institutions (Cohen et al., 2002; Cockburn and Henderson, 1998; Fabrizio, 2009).

An illustrative example is the biotechnology industry, which has strong links to Open Science. Small and medium-sized biotechnology firms often license basic research findings to established pharmaceutical firms that have the complementary assets to implement the research inputs to produce actual drugs (Powell et al., 1996). In this example, upstream biotechnology R\&D is clearly an input to downstream $R \& D$, although it is less evident whether this relationship holds in the opposite direction (see also Harhoff, 1996). However, given the facilitated possibilities of transferring tacit knowledge in supply chain relationships as a result of repeated interactions at the individual level, there is a rationale to expect, overall, a positive impact of buyer innovation on supplier innovation.

H1. Buyer technological innovation has a positive impact on supplier technological innovation.

\subsection{Relationship duration}

Firms that engage in transactions may be required to invest in the relationship, and subsequently also develop specific assets (Williamson, 1985). More specifically, firms that intend to learn from supply chain partners may be required to develop an absorptive capacity that is specific to the relationship (Lane and Lubatkin, 1998; Dyer and Singh, 1998). A supply chain relationship is typically associated with 
repeated interactions between different individuals, enabling the exchange of valuable tacit knowledge. However, as a precondition, the scientists and engineers involved have to get to know one another in order to identify who has critical expertise. Moreover, individuals have to develop an understanding as to which knowledge can be shared or should remain within the firm (Dyer and Singh, 1998; Powell et al., 1996) and they have to use a common language for interaction (Kogut and Zander, 1992). Therefore, supply chain partners may benefit from increasing experience and from explicit organizational efforts to achieve efficient communication and dedicated coordination with partners (Nelson and Winter, 1982; Dyer and Singh, 1998; Kotabe et al., 2003). Since the implementation of knowledge sharing routines and a relationship-specific absorptive capacity is a cumulative process that evolves over time (see also Levinthal and Fichman, 1988; Fichman and Levinthal, 1991), it can be expected that the relationship duration has a positive moderating impact on knowledge spillovers from a buyer to a supplier.

H2. The impact of buyer technological innovation on supplier technological innovation is positively moderated by the duration of the relationship between the supplier and its buyers.

\subsection{Technological proximity}

The learning possibilities for a firm are likely not homogeneous across supply chain partners. In the previous subsection we identified a firm's absorptive capacity as a potentially important facilitator of knowledge spillovers. Beyond the implementation of routines to increase relation-specific absorptive capacity, the basic level of a firm's absorptive capacity is mainly determined by the overlap in the technological portfolios between the focal firm and the external knowledge source (Cohen and Levinthal 1989, 1990; Dyer and Singh, 1998). If the scope of R\&D is similar between suppliers and buyers, it should require less effort for the supplier to absorb knowledge outcomes from the buyer and to recombine them into its own technological outcomes. If a buyer and supplier perform research in the same or closely related areas, the R\&D personnel of the supplier should be able to more easily recognize the complementarities between the supplier's own knowledge base and the incoming external knowledge.

In addition to increased absorptive capacity, the innovation activities of closely related buyers should be more relevant for the supplier in absolute terms, increasing the "pool" of knowledge that can potentially be absorbed. These two mechanisms should lead to higher benefits from knowledge inflows when the supply chain partners have a proximate position in the technological space (see also Stuart and Podolny, 1996; Jaffe, 1986). It is possible for firms to achieve radical innovations if external, technologically distant knowledge is combined with their own knowledge base (Rosenkopf and Nerkar, 2001). However, technologically distant knowledge that is relevant for a firm is also more difficult to identify and absorb. Therefore, although the prediction is not unambiguous from a theoretical viewpoint, we expect a positive moderating effect of the technological proximity between buyers and suppliers. 
H3. The impact of buyer technological innovation on supplier technological innovation is positively moderated by the technological proximity between the supplier and its buyers.

\section{Methodology}

\subsection{Data}

Our analysis relies on a large-scale data set of U.S. firms that combines information from several data sources on buyer-supplier relations, financial accounting statements, and patent data. The basic empirical context is stock-market listed U.S. firms in high-technology sectors (biotechnology and pharmaceuticals, scientific and medical instruments, aircraft and aerospace, and chemicals). These industries are chosen using OECD's technology intensity definition, which is a classification of manufacturing industries based on their average R\&D intensity (Hatzichronoglou, 1997). In light of our research question, these firms are an ideal setting because of their innovativeness, their dependence on continuous knowledge creation, and the importance of formal intellectual property. The latter is also important with respect to the empirical strategy that relies on patents as a measure of innovation. The industries included are listed in Table 1.

-- Insert Table 1 about here --

We combine buyers and suppliers by drawing on a financial accounting standard regarding the disclosure of major customers. Paragraph 39 in financial accounting standard 131 stipulates that firms must report if revenues from a single customer exceed $10 \%$ of total sales (FAS, 1997). Although it is not mandatory to report the identity of the customer, most firms do so (and sometimes also do so even if sales do not exceed $10 \%$ of total sales).

Since the customers are filed by company name, we use a matching algorithm that takes typos and abbreviations into account. For example, for General Motors one can find entries such as GM, General Motors Company, G. Motors and G. Mtrs, which have to be matched with a unique company identifier such as the CUSIP or ticker codes. After the algorithm-based allocation, the matches are manually reviewed. Unfortunately, the matching between customers' names with Compustat information leads to ambiguities (e.g. multiple firms listed in Compustat are allocated) that can partly not be resolved manually. In such cases we are restrictive and exclude those observations. Moreover, some firms do not report the customer name, or they have government authorities and non-Compustat firms listed as major 
customers. For the final sample, we extract yearly financial accounting data from Standard \& Poor's Compustat. $^{2}$

This panel of firm-level data is combined with patent data from the Worldwide Patent Statistical database (Patstat) using name-based matching procedures. We consider the application date of granted patents to capture the period when the knowledge was created. The patent matching is done using a matching algorithm that queries the firm names in the applicant field of the Patstat database. Prior to the matching, an extensive cleaning and pre-testing of the firm names was carried out. After the matching, comprehensive manual checks were performed with a specific focus on firms with high patent/R\&D ratios and problematic names (as detected in the pre-tests).

For the final sample, extreme outliers, observations with economically insignificant values (e.g. negative sales) and firms with no R\&D investment or patenting during the sample period are removed. ${ }^{3}$ We also exclude dyads consisting of affiliated firms and subsidiaries. Our final data set contains complete information on 230 suppliers between the years 1990 and 2006 (a total of 706 supplier observations). The sample period ends in 2006, since we use five years of forward citations as a control of patent quality, as outlined in Section 4.2. Table 2 shows descriptive statistics for the buyers and suppliers in our sample. We note that the suppliers in our sample are considerably smaller than the buyers. This is because of the accounting standard regarding the disclosure of major customers that is used for the data collection. These size differences are helpful for the identification strategy in our econometric analysis and will be discussed further in Section 4.3.

-- Insert Table 2 about here --

\subsection{Variables}

To test our hypotheses, we include measures that capture the innovation activities of the buyers and suppliers, respectively. These include R\&D investments and patents. We use patent productivity, $\log$ Supp Pat Prod (number of patents, scaled by R\&D expenditure to account for differences in input), as our core measure of supplier innovation (Hall et al., 2005; Lanjouw and Schankerman, 2004). To capture

\footnotetext{
${ }^{2}$ The following is an example of the buyer-supplier data structure: In 1990 Megatest Corp. had $\$ 75.4$ million in total sales. It sold $\$ 8.7$ million (11.5\%) to Intel Corp. and \$9.3 million (12.3\%) to Micron Technology Inc. The remaining buyers are not observed. In 1991 we still observe Intel Corp. and Micron Technology Inc. as buyers but in addition also Texas Instruments Inc.

${ }^{3}$ We exclude firms that did not invest in R\&D or did not file a patent at all during our sample period. However, it is still possible that a firm has no $\mathrm{R} \& \mathrm{D}$ investment or zero patents in a given year. The rationale for excluding these firms is to avoid bias by firms with no innovation activities.
} 
the absolute size of buyer innovative output potentially absorbed by the supplier, we consider the variable Log Buy Pat Count, which denotes the total amount of buyer patents in a given year. We take into account that patents are highly skewed in their technological and economic value. In the innovation literature, patent forward citations are regarded as an informative quality measure (Jaffe et al., 2000; Nelson, 2009; Trajtenberg, 1997). We construct the variable Log Forw Cit Int by counting citations within a five-year window starting from the priority date and scaling by patent count. As an additional measure, innovative input is measured as $\mathrm{R} \& \mathrm{D}$ scaled by assets, $\log R D$ Int. We include the $\mathrm{R} \& \mathrm{D}$ measure for both suppliers and buyers. We take the natural logarithm of all the above variables to reduce the effect of outliers. ${ }^{4} \mathrm{We}$ also test joint patents but find only eight cases where the buyer and supplier co-patent.

To test Hypothesis 2, we use the number of years that a buyer and supplier are linked in our data set as a measure of the duration (Duration) of the relationship. ${ }^{5}$ Technological proximity (Tech Prox) is measured by determining whether the two firms are in the same industry on different levels of SIC-code aggregation (using 2, 3, and 4 digit SIC-codes) (Orlando, 2004). Since not all firms in our sample file for patents, applying patent-based proximity measures (e.g. Jaffe 1986) would imply a considerable loss of observations.

In addition to the core measures, we include further controls to take firm heterogeneity into account. To account for heterogeneities in firm size we control for the sales of the buying and supplying firms (Log Sales). We also include the variable Buyer Count to control for the number of observed buyers in a given year in order to capture buyer entry and exit.

\subsection{Econometric specification}

Each supplier in our data set is observed over time. At the same time, a supplier can have several buyers in a given year, and vice versa. Both buyers and suppliers can enter and exit the panel. Unlike a standard two-dimensional panel we therefore potentially have unobserved heterogeneity on both the buyer and the supplier dimensions.

In order not to bias our results by suppliers with many buyers (which would lead to multiple observations for a single supplier in a given year), we aggregate our data at the supplier dimension (McGahan and Silverman, 2006). For each supplier-year observation we calculate a weighted average for each observed buyer characteristic. ${ }^{6}$ Our data set hence reduces to a standard two-dimensional panel

\footnotetext{
${ }^{4}$ We make the transformation $\ln (1+$ variable) as suggested by Jaffe (1986).

${ }^{5}$ We acknowledge that this proxy has limitations as the dyad could have existed without being present in the data set.

${ }^{6}$ For example, aggregate buyer sales is the average sales of all buyers connected to the supplier i in year $t$, weighted by the amount of sales between the supplier and each buyer.
} 
with unique supplier-year observations. Table 3 shows the correlation between the variables described in Section 4.2 after aggregation.

-- Insert Table 3 about here --

We estimate the following econometric model:

Log_Supp_Pat_Prod $d_{i t}=$

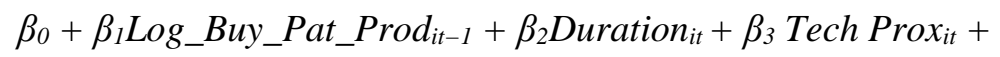

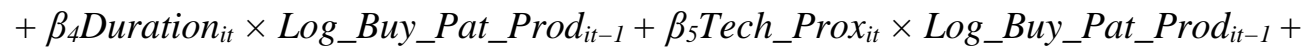

$+\sum_{j=1}^{k} \beta_{j} X_{i t}^{j}+F i+\mu_{t}+e_{i t}$

Where $F_{i}$ denotes supplier fixed effects, $\mu_{\mathrm{t}}$ year fixed effects, $X_{i t}$ the set of control variables described in Section 4.2 and $e_{i t}$ the error term. Like Bloom et al. (2013), we lag the main dependent variable, Log Buy Pat Prod, by one year to avoid simultaneity bias and to allow for a time delay in potential knowledge spillovers.

To control for time-invariant unobserved heterogeneity, we rely on the "within"-fixed effects estimator. Since the estimator only explains variation over time for a given firm, we control for all factors that are time invariant such as geographic location, firm culture, industry, and all time-variant company characteristics preceding the sample period. There are two sources of within-variation in our data: 1) the independent variables of interest can change directly over time (the number of patents changes every year for a given buyer) and 2) the buyers that are linked to a supplier enter and exit the panel over the years. ${ }^{7}$ To ensure consistent standard errors we correct for potentially autocorrelated residuals by running all regressions with cluster robust standard errors. In addition we use an estimator that allows for lag-1 autocorrelated residuals.

With regard to our econometric analysis, we acknowledge several potential sources of endogeneity. The first relates to the possibility that supplier innovation is positively impacting buyer innovation, rather than vice versa. Reverse causality may also affect the moderating effect of relationship duration as the buyer may prefer to sustain the supply chain relationship with an innovative supplier, resulting in longer relationship duration. However, the size differences (between buyers and suppliers in our sample) in the dimensions R\&D expenditures, patent counts, and firm size should reduce this concern. The

\footnotetext{
${ }^{7}$ One of our variables of interest, the technological proximity between supplier and buyer, only has one source of within-variation. This comes from the entry or exit of buyers over time.
} 
suppliers in our sample are considerably smaller than their average buyer, which makes it relatively unlikely that a change in their innovative productivity has a significant impact on the innovative output of the buyer. Furthermore, we lag the independent variable (Log Buy Pat Count) by one year. Our results could also be driven by selection-i.e. we could find evidence of knowledge spillovers from buyers to suppliers because innovative buyers tend to work with innovative suppliers. However, this potential mechanism should be mitigated by taking the innovativeness and the innovative input of the supplier into consideration. By observing the dyads over time and using a fixed effects panel data model, we account for the degree of innovativeness of the supplier before it enters our sample (and hence also when the selection decision is made). Moreover, by including $R \& D$ intensity we control for the innovative input in each observed year. Further potential sources of endogeneity may arise from omitted variables that are simultaneously correlated with the innovative output of the buyer and the supplier, such as technology specific shocks.

\section{$5 \quad$ Results and discussion}

The results of our econometric analysis are shown in Table 4. Our first interest concerns the unconditional effect of buyer innovation Log Buy Pat Count $t_{t-1}$ without considering the moderating factors, which are reported in columns (1)-(2).

-- Insert Table 4 about here --

Starting with an OLS model (1), a $1 \%$ increase in patents at the buyer, on average, leads to a $0.0227 \%$ increase in patent productivity for the supplier. Taking firm-fixed effects into account (2), the magnitude decreases only marginally to $0.0211 \%$. Consequently, we find strong support for Hypothesis 1. Concerning the R\&D intensity of the buyer, we do not detect any significant effects across model specifications. However, this is not surprising, since R\&D investments reflects the same, or very similar, knowledge as our main independent variable and is introduced as intensity measure.

Following our discussion in the conceptual part, we examine the influence of the two moderating factors as indicated in Hypotheses 2 and 3, namely Duration and Technological Proximity. In models (3) and (4) we introduce the corresponding interaction terms separately, before estimating the full regression model with both interactions (5). Model (6) expands (5) by allowing for lag-1 autocorrelated residuals. When doing so, the observations with only one year of relationship duration are lost by construction. The sign and significance levels remain consistent, largely confirming the results of our main regression model (5), which are discussed below: 
The regression results suggest that relationship duration is indeed a relevant moderating factor since we find a positive and highly significant interaction term. As one would expect, the duration variable has no positive impact as such, but it considerably amplifies the effect of knowledge spillovers. This result is in line with the consideration that firms need to build up a relation-specific absorptive capacity in order to benefit from technological outcomes of buying firms. To shed more light on the impact of the relationship duration, we compute the marginal effects of varying average relationship durations as reported in Table 5. Interestingly, buyer technological innovation has little or no impact on suppliers' innovative outcomes during the first year. However, the magnitudes increase over time, and the variable becomes statistically significant starting from the second year onwards. From a learning point of view, this results suggests that any changes in partners should take into account that firms need considerable time before knowledge spillovers can be successfully absorbed.

-- Insert Table 5 about here --

Finally, we analyze the technological proximity between the supplier and its buyers, but do not find a statistically significant effect. As discussed in Section 3, the theoretical prediction is ambiguous, although we would have expected a positive impact overall. This indicates that learning from technological outcomes of buyers is possible in terms of both relatively proximate and distant knowledge. It is also necessary to keep in mind that there is already an intrinsic selection in terms of technological proximity from the formation of the supply chain relationship, which already implies a certain proximity. An alternative explanation could lie in the possibility that sector classifications may insufficiently capture the overlap in the technological portfolios. Therefore, one has to be cautious in drawing far-reaching conclusions based on our results on technological proximity.

Overall, we provide econometric evidence that buyers are an important source of learning with regard to technological innovation. This is an interesting result given that one might expect that universities and public research institutions would be more relevant learning sources in high-technology sectors. Moreover, our results strongly suggest that building up long-term relationships can be a rewarding strategy.

\section{Robustness checks}

Our main result—-that buyer innovation positively influences supplier innovation—also remains stable across numerous alternative specifications (see Table 6). Models (1)-(2) show fixed effects and random effects regressions with similar outcomes. To investigate whether suppliers with no patents in a given 
year might bias our results, we run a Tobit panel regression (model 3). The results remain very similar to other specifications, indicating that left-censoring is not masking the true effect.

-- Insert Table 6 about here --

We also try a different specification without lagging the independent variable Log Buy Pat Count. We find that buyer innovation in year $t$ does not significantly impact supplier innovation in year $t$ (model 4). This would suggest that it takes time for the supplier to absorb and utilize the knowledge. In model (5) the control variables are lagged by 1 year showing similar results to model (1). Moreover, we split our sample into two groups based on the average size difference between the supplier and its buyers. We find a spillover effect for the group with large size differences but no significant effect in the group with small size differences (see models $6 \& 7$ ). We also estimate two count models ( $8 \& 9$ ) as robustness checks. Both the negative binomial and the Poisson panel regressions yield significant and positive coefficients. Finally we also test a model where we scale buyer patent count by R\&D. The effect remains positive and significant.

\section{Conclusion}

This study provides novel empirical evidence on knowledge spillovers in supply chains. We analyze knowledge spillovers between buyers and suppliers, as well as central factors that govern this phenomenon. We find both statistically and economically significant evidence that buyer innovation positively influences supplier innovation. We also show that knowledge spillovers from buyers to suppliers are positively moderated by the duration of the relationship between the two firms. The results do not support the hypothesis that knowledge spillovers increase the more similar a supplier is to its buyers in terms of technology.

The notion that buyer innovation positively affects supplier innovation and that the relationship duration is an important moderating effect offers some interesting insights. Our results provide a rationale for supply chain and $R \& D$ managers to engage in longer-term relationships as the benefits of external knowledge increase over time. Although we cannot directly observe the micro-mechanism behind this result, it suggests that the development of a relation-specific absorptive capacity and routines for learning is important. This implies that suppliers can benefit from active knowledge management and the development of routines, allowing them to accelerate the absorption of relevant buyer knowledge. However, firms-in our context the buying firms-should also consider the fact that knowledge flows out. While knowledge flows to suppliers can improve the supply chain performance 
as a whole, the supplier might learn more than what was intended and suppliers may start to compete in certain product markets.

Our study comes with several limitations that future research could try to address. First, our results could be driven by endogeneity and selection effects. In particular, unobserved mechanisms relevant for the formation and continuation of buyer-supplier relationships could lead to an overestimation of spillovers as well as relationship duration as a moderating factor. Similarly, we cannot entirely exclude the effect of reverse causality and the fact that supplier innovation also can impact buyer innovation. Second, we do not observe the full set of buyers connected to the suppliers in our sample. An assumption in our model is therefore that the observed buyers are representative of the whole set. If this assumption does not hold, our results could be biased. Third, all buyers and suppliers in our sample are publicly traded U.S. firms, which may limit the generalizability of our results. Our sample construction intrinsically implies a close geographical (and cultural) proximity compared with global suppliers. While such proximity could increase the magnitude of spillovers, knowledge from more distant suppliers might also lead to more radical innovations.

Future research could address these questions by analyzing samples based on plant level (Todo et al., 2015) or global sourcing (Jain et al., 2013) data. Although this was beyond the scope of our study, future research could also investigate the relative importance of tacit and codified knowledge transfers. Admittedly, this is a challenging endeavor, but detailed surveys and case studies could provide additional insights. 


\section{References}

Aldieri, L., Cincera, M., 2009. Geographic and technological R\&D spillovers within the triad: micro evidence from US patents. Journal of Technology Transfer 34, 196-211.

Alcacer, J., Chung, W., 2007. Location strategies and knowledge spillovers. Management Science 53 (5), 760-776.

Almeida, P., Kogut, B., 1997. The exploration of technological diversity and the geographic localization of innovation. Small Business Economics 9, 21-31.

Antras, P., Helpman, E., 2004. Global sourcing. Journal of Political Economy 112 (3), 552-580.

Appleyard, M.M., 2003. The influence of knowledge accumulation on buyer-supplier codevelopment projects. Journal of Product Innovation Management 20 (5), 356-373.

Audretsch, D.B., 1995. Innovation, growth and survival. International Journal of Industrial Organization 13 (4), 441-457.

Azadegan, A., Dooley, K.J., 2010. Supplier innovativeness, organizational learning styles and manufacturer performance: an empirical assessment. Journal of Operations Management 28 (6), 488 505 .

Belderbos, R., Carree, M., Lokshin, B., 2004. Cooperative R\&D and firm performance. Research Policy $33,1477-1492$.

Bloom, N., Schankerman, M., Van Reenen, J., 2013. Identifying technology spillovers and product market rivalry. Econometrica 81 (4), 1347-1393.

Cassiman, B., Veugelers, R., 2002. R\&D cooperation and spillovers: some empirical evidence from Belgium. American Economic Review 92 (4), 1169-1184.

Cefis, E., Marsili, O., 2006. Survivor: the role of innovation in firms' survival. Research Policy 35 (5), 626-641.

Chatterji, A.K., Fabrizio, K., 2012. How do product users influence corporate invention? Organization Science 23 (4), 971-987.

Chesbrough, H., 2003. Open Innovation. Harvard University, Cambridge, MA.

Cockburn, I.A., Henderson, R.M., 1998. Absorptive capacity, co-authoring behaviour, and the organization of research in drug discovery. Journal of Industrial Economics 46 (2), 157-182.

Cohen, W.M., Levinthal, D.A., 1989. Innovation and learning: the two faces of R\& D. The Economic Journal 569-596.

Cohen, W.M., Levinthal, D.A., 1990. Absorptive capacity: a new perspective on learning and innovation. Administrative Science Quarterly 35 (1), 128-152.

Cohen, W.M., Nelson, R.R., Walsh, J.P., 2002. Links and impacts: The influence of public research on industrial R\&D. Management Science 48 (1), 1-23.

Cowan, R., David, P.A., Foray, D., 2000. The explicit economics of knowledge codification and tacitness. Industrial and Corporate Change 9 (2), 211-253.

Dahlander, L., Gann, D. M., 2010. How open is innovation? Research Policy 39, 699-709.

De Jong, J.P.J., von Hippel, E., 2009. Transfers of user process innovations to process equipment producers: a study of Dutch high-tech firms. Research Policy 38 (7), 1181-1191.

Dyer, J.H., Singh, H., 1998. The relational view: cooperative strategy and sources of interorganizational competitive advantage. Academy of Management Review 23 (4), 660-679. 
Fabrizio, K.R., 2009. Absorptive capacity and the search for innovation. Research Policy 38, 255-267.

FAS., 1997. Statement of financial accounting standards No.131. http://www.fasb.org/cs

Feldman, M., 1999. The new economics of innovation, spillovers and agglomeration: a review of empirical studies. Economics of Innovation and New Technology 8 (1-2), 5-25.

Fichman, M., Levinthal, D.A., 1991. Honeymoons and the liability of adolescence: A new perspective on duration dependence in social and organizational relationships. Academy of Management Review $16(2), 442-468$.

Görg, H., Strobl, E., 2001. Multinational companies and productivity spillovers: A meta-analysis. Economic Journal 111 (475), 723-739.

Hall, B.H., Jaffe, A., Trajtenberg, M., 2005. Market value and patent citations. RAND Journal of Economics 36 (1), 16-38.

Harhoff, D., 1996. Strategic spillovers and incentives for research and development. Management Science 42, 907-925.

Hatzichronoglou, T., 1997. Revision of the high-technology sector and product classification. OECD Publishing. OECD Science, Technology and Industry Working Papers. http://dx.doi.org/10.1787/134337307632.

Havranek, T., Irsova, Z., 2011. Estimating vertical spillovers from FDI: Why results vary and what the true effect is. Journal of International Economics 85, 234-244.

Ikeuchi, K., Belderbos, R., Fukao, K., Kim, Y.G., Kwon, H.U., 2015. Buyers, Suppliers, and R\&D spillovers. Working Paper.

Jaffe, A., 1986. Technological opportunity and spillovers of R\&D: evidence from firms patents, profits, and market value. American Economic Review 76, 984- 1001.

Jaffe, A.B., Trajtenberg, M., Henderson, R., 1993. Geographic localization of knowledge spillovers as evidenced by patent citations. Quarterly Journal of Economics 108 (3), 577-598.

Jaffe, A.B., Trajtenberg, M., Fogarty, M.S., 2000. The meaning of patent citations: report of the NBER/Case-Western reserve survey of patentees. NBER Working Paper no. 7631.

Jain, N., Girotra, K., Netessine, S., 2013. Managing global sourcing: inventory performance. Management Science 60 (5), 1202-1222.

Javorcik, B.S., 2004. Does foreign direct investment increase the productivity of domestic firms? In search of spillovers through backward linkages. American Economic Review 94 (3), 605-627.

Jeppesen, L.B., Frederiksen, L., 2006. Why do users contribute to firm-hosted user communities? The case of computer-controlled music instruments. Organization Science 17 (1), 45-63.

Kogut, B., Zander, U., 1992. Knowledge of the firm, combinative capabilities, and the replication of technology. Organization Science 3 (3), 383-397.

Kotabe, M., Martin, X., Domoto, H., 2003. Gaining from vertical partnerships: Knowledge transfer, relationship duration, and supplier performance improvement in the U.S. and Japanese automotive industries. Strategic Management Journal 34, 293-316.

Lane, P.J., Lubatkin, M., 1998. Relative absorptive capacity and interorganizational learning. Strategic Management Journal 19, 461-477.

Lanjouw, J. O., M. Schankerman. 2004. Patent quality and research productivity: Measuring innovation with multiple indicators. The Economic Journal 114(495) 441-465. 
Laursen, K., Salter, A., 2006. Open for innovation: the role of openness in explaining innovation performance among U.K. manufacturing firms. Strategic Management Journal 27 (2), 131-150.

Levinthal, D.A., Fichman, M., 1988. Dynamics of interorganizational attachments: auditor-client relationships. Administrative Science Quarterly 33 (3), 345-369.

Lychagin, S., Pinkse, J., Slade, M.E., Van Reenen, J., 2010. Spillovers in space: does geography matter? NBER working paper 16188.

Mairesse, J., Mulkay, B., 2008. An exploration of local R\&D spillovers in France. NBER working paper 14552.

McGahan, A.M., Silverman, B.S., 2006. Profiting from technological innovation by others: the effect of competitor patenting on firm value. Research Policy 35 (8), 1222-1242.

Meyer, K.E., Sinani, E., 2009. When and where does foreign direct investment generate positive spillovers? A meta-analysis. Journal of International Business Studies 40 (7), 1075-1094.

Nelson, A.J., 2009. Measuring knowledge spillovers: what patents, licenses and publications reveal about innovation diffusion. Research Policy 38, 994-1005.

Nelson, R.R., Winter, S.G., 1982. An Evolutionary Theory of Economic Change. Belknap Press of Harvard University Press, Boston.

Orlando, M.J., 2004. Measuring spillovers from industrial R\&D: on the importance of geographic and technological proximity. RAND Journal of Economics 35 (4), 777-786.

Petersen, K.J., Handfield, R.B., Ragatz, G.L., 2005. Supplier integration into new product development: coordinating product, process and supply chain design. Journal of Operations Management 23 (3-4), $371-388$

Powell, W.W., Koput, K.W., Smith-Doerr, L., 1996. Interorganizational collaboration and the locus of innovation: networks of learning in biotechnology. Administrative Science Quarterly 41 (1), 116145 .

Primo, M.A.M, Amundson, S.D., 2002. An exploratory study of the effects of supplier relationships on new product development outcomes. Journal of Operations Management 20 (1), 33-52.

Rosenkopf, L., Nerkar, A., 2001. Beyond local search: boundary-spanning, exploration, and impact in the optical disk industry. Strategic Management Journal 22, 287-306.

Salioli, F., Zanfei, A., 2009. Multinational firms, global value chains and the organization of knowledge transfer. Research Policy 38, 369-381.

Schumpeter, J.A., 1942. Capitalism, Socialism and Democracy. Harper \& Row, New York.

Shaver, J.M., Flyer, F., 2000. Agglomeration economies, firm heterogeneity, and foreign direct investment in the United States. Strategic Management Journal 21, 1175-1193.

Stuart, T.E., Podolny, J.M., 1996. Local search and the evolution of technological capabilities. Strategic Management Journal 17, 21-38.

Sturgeon, T., Van Biesebroeck, J., Gereffi, G., 2008. Value chains, networks and clusters: reframing the global automotive industry. Journal of Economic Geography (2008), 1-25.

Todo, Y., Matous, P., Inoue, H., 2015. The strength of long ties and the weakness of strong ties: Knowledge diffusion through supply chain networks. Working paper. Research Institute of Economy, Trade and Industry (RIETI).

Trajtenberg, M., 1997. A penny for your quotes: patent citations and the value of innovations. The RAND Journal of Economics 21 (1), 172-187. 
Von Hippel, E., 1976. The dominant role of users in the scientific instrument innovation process. Research Policy (5), 212-239.

Von Hippel, E., Thomke, S., Sonnack, M., 1999. Creating breakthroughs at 3M. Harvard Business Review, Reprint No. 99510.

Von Hippel, E., Von Krogh, G., 2003. Open Source software and the private-collective innovation model: Issues for organization science. Organization Science 14 (2), 209-223.

Williamson, O. E. 1985. The Economic Institutions of Capitalism. Free Press, New York. 
Table 1: Sample composition

\begin{tabular}{|c|c|c|c|}
\hline Meta-Sector & SIC included & Suppliers & Buyers \\
\hline Biotechnology \& Pharmaceuticals & $2834,2835,2836$ & 23 & 14 \\
\hline Chemicals & $2800,2810,2820,2821,2833$ & 241 & 470 \\
\hline $\begin{array}{l}\text { Information and Communication } \\
\text { Technologies (ICT) }\end{array}$ & $\begin{array}{l}3570,3571,3572,3575,3576,3577,3578,3579,3661 \text {, } \\
3663,3669,3670,3672,3674,3677,3678,3679,4812 \text {, } \\
4813,4822\end{array}$ & 196 & 477 \\
\hline Aircraft \& Aerospace & $3721,3724,3728$ & 33 & 67 \\
\hline $\begin{array}{l}\text { Navigation, Scientific, Medical, and } \\
\text { Optical instruments }\end{array}$ & $\begin{array}{l}3812,3822,3823,3824,3825,3826,3827,3829,3841 \text {, } \\
3842,3843,3844,3845,3851,3861\end{array}$ & 213 & 289 \\
\hline Sum & & 706 & 1317 \\
\hline
\end{tabular}

Table 2: Buyer and supplier characteristics before aggregation

\begin{tabular}{lccccc}
\hline & Mean & Median & S.D. & Min & Max \\
\hline Buyers & & & & & \\
Patents & 160.5 & 41 & 313.2 & 0 & 2448 \\
Forward citations & 1090.2 & 211 & 2314.2 & 0 & 20606 \\
R\&D (USD million) & 935.9 & 319.5 & 1395.3 & 0.32 & 12942.2 \\
Sales (USD million) & $10,751.2$ & 3078 & $16,115.3$ & 0.46 & 97557.7 \\
& & & & & \\
Suppliers & 10.1 & 2 & 40.1 & 0 & 669 \\
Patents & 66.5 & 8 & 295.4 & 0 & 6,364 \\
Forward citations & 61.9 & 12 & 242.5 & 0.002 & $3,439.8$ \\
R\&D (USD million) & 823.4 & 33.9 & 3298.9 & 0.02 & 39220.3 \\
Sales (USD million) & & & & & \\
Tie Strength & $26 \%$ & $17 \%$ & $23 \%$ & $0.001 \%$ & $100 \%$ \\
\hline
\end{tabular}


Table 3: Descriptive statistics and correlations

\begin{tabular}{|c|c|c|c|c|c|c|c|c|c|c|c|c|}
\hline & Mean & S.D. & (1) & (2) & (3) & (4) & (5) & (6) & (7) & (8) & (9) & (10) \\
\hline (1) Log Supp Pat Prod & 0.22 & 0.28 & 1 & & & & & & & & & \\
\hline (2) Log Lagged Buy Pat Count & 4.11 & 2.09 & 0.045 & 1 & & & & & & & & \\
\hline (3) Duration & 3.66 & 2.05 & 0.051 & $0.11 * *$ & 1 & & & & & & & \\
\hline (4) Tech Prox & 0.33 & 0.46 & $0.086^{*}$ & $-0.11 * *$ & -0.052 & 1 & & & & & & \\
\hline (5) Buyer Count & 1.15 & 0.39 & -0.073 & $0.11 * *$ & $-0.12 * *$ & -0.037 & 1 & & & & & \\
\hline (6) Log Buy Frwd Cit Int & 1.72 & 0.72 & $-0.12 * * *$ & $0.40 * * *$ & $-0.086^{*}$ & $-0.085^{*}$ & 0.067 & 1 & & & & \\
\hline (7) Log Supp R\&D Int & 0.16 & 0.14 & $-0.10 * *$ & $-0.091 *$ & $-0.21 * * *$ & $0.088^{*}$ & $0.16^{* * *}$ & $-0.088^{*}$ & 1 & & & \\
\hline (8) Log Buy R\&D Int & 0.08 & 0.05 & 0.043 & $0.086^{*}$ & $-0.13 * * *$ & $0.30 * * *$ & $0.092 *$ & 0.049 & $0.29 * * *$ & 1 & & \\
\hline (9) Log Supp Sales & 4.16 & 2.19 & 0.0071 & $0.10 * *$ & $0.25 * * *$ & $-0.10 * *$ & $-0.16 * * *$ & $0.11 * *$ & $-0.51 * * *$ & $-0.28 * * *$ & 1 & \\
\hline (10) Log Buy Sales & 8.88 & 1.71 & $-0.079 *$ & $0.52 * * *$ & $0.12 * *$ & $-0.26 * * *$ & -0.0046 & $0.27 * * *$ & $-0.12 * *$ & $-0.26 * * *$ & $0.35 * * *$ & 1 \\
\hline
\end{tabular}


Table 4: Regression outputs

\begin{tabular}{|c|c|c|c|c|c|c|}
\hline Log Supp Pat Prod & (1) & $(2)$ & (3) & (4) & $(5)$ & (6) \\
\hline \multirow[t]{2}{*}{ Log Buy Pat Count $_{t-1}$} & $0.0227 * *$ & $0.0211 * *$ & 0.00646 & $0.0266 * * *$ & 0.0116 & -0.00852 \\
\hline & $(0.00923)$ & $(0.00859)$ & $(0.0112)$ & $(0.00889)$ & $(0.0115)$ & $(0.0166)$ \\
\hline \multirow[t]{2}{*}{ Log Buy Pat Count $_{t-1} \times$ Duration } & & & $0.00508 * * *$ & & $0.00503 * *$ & $0.00917 * *$ \\
\hline & & & $(0.00193)$ & & $(0.00194)$ & $(0.00363)$ \\
\hline \multirow[t]{2}{*}{ Log Buy Pat Count $_{t-1} \times$ Tech Prox } & & & & -0.0150 & -0.0138 & -0.0310 \\
\hline & & & & $(0.0218)$ & $(0.0223)$ & $(0.0304)$ \\
\hline \multirow[t]{2}{*}{ Duration } & -0.00170 & -0.00161 & $-0.0243 * *$ & -0.00264 & $-0.0251 * *$ & -0.0339 \\
\hline & $(0.00771)$ & $(0.00807)$ & $(0.00945)$ & $(0.00841)$ & $(0.00976)$ & $(0.0210)$ \\
\hline \multirow[t]{2}{*}{ Tech Prox } & 0.0624 & -0.0344 & -0.0305 & 0.0209 & 0.0203 & -0.0490 \\
\hline & $(0.0525)$ & $(0.0784)$ & $(0.0800)$ & $(0.117)$ & $(0.122)$ & $(0.120)$ \\
\hline \multirow[t]{2}{*}{ Buyer Count } & -0.0510 & -0.0108 & -0.00610 & -0.0107 & -0.00613 & 0.0121 \\
\hline & $(0.0313)$ & $(0.0240)$ & $(0.0243)$ & $(0.0240)$ & $(0.0242)$ & $(0.0483)$ \\
\hline \multirow[t]{2}{*}{ Log Buy Frwd Cit Int } & $-0.0542 * *$ & -0.00816 & -0.00943 & -0.00777 & -0.00907 & -0.0353 \\
\hline & $(0.0238)$ & $(0.0160)$ & $(0.0169)$ & $(0.0158)$ & $(0.0166)$ & $(0.0309)$ \\
\hline \multirow[t]{2}{*}{ Log Supp R\&D Int } & -0.194 & -0.184 & -0.181 & -0.182 & -0.179 & -0.219 \\
\hline & $(0.138)$ & $(0.141)$ & $(0.138)$ & $(0.138)$ & $(0.135)$ & $(0.202)$ \\
\hline \multirow[t]{2}{*}{ Log Buy R\&D Int } & 0.198 & 0.139 & 0.0867 & 0.124 & 0.0727 & -0.0305 \\
\hline & $(0.308)$ & $(0.341)$ & $(0.338)$ & $(0.335)$ & $(0.333)$ & $(0.659)$ \\
\hline \multirow[t]{2}{*}{ Log Supp Sales } & 0.0169 & -0.00795 & -0.00550 & -0.00720 & -0.00483 & -0.00434 \\
\hline & $(0.0131)$ & $(0.0220)$ & $(0.0213)$ & $(0.0216)$ & $(0.0209)$ & $(0.0317)$ \\
\hline \multirow[t]{2}{*}{ Log Buy Sales } & -0.00127 & -0.00410 & -0.00391 & -0.00563 & -0.00532 & -0.0169 \\
\hline & $(0.0104)$ & $(0.0124)$ & $(0.0124)$ & $(0.0121)$ & $(0.0119)$ & $(0.0351)$ \\
\hline Industry Fixed Effect Included & Yes & Yes & Yes & Yes & Yes & Yes \\
\hline Firm Fixed Effects-Included & No & Yes & Yes & Yes & Yes & Yes \\
\hline Year Effects Included & Yes & Yes & Yes & Yes & Yes & Yes \\
\hline Observations & 706 & 706 & 706 & 706 & 706 & 476 \\
\hline Suppliers & 230 & 230 & 230 & 230 & 230 & 156 \\
\hline Within R-Square & $0.191^{\dagger}$ & 0.0651 & 0.0744 & 0.0662 & 0.0753 & 0.121 \\
\hline F Statistic & $4.210 * * *$ & 1.097 & 1.375 & 1.227 & $1.430 *$ & $1.772 * *$ \\
\hline
\end{tabular}

Note: $* * * \mathrm{p}<0.01, * * \mathrm{p}<0.05, * \mathrm{p}<0.1{ }^{\dagger}$ OLS R-Square. Cluster robust standard errors in parentheses

(1) Baseline OLS regression. (2) Baseline fixed effects regression. (3) FE: Interaction between buyer patent count and duration. (4) FE: Interaction between buyer patent count and technological proximity. (5) Full FE model. (6) Full FE model allowing for lag-1 autocorrelated residuals. 
Table 5: Marginal effects of relationship duration over time

\begin{tabular}{cl}
\hline Duration (years) & Log Buy Pat Count ${ }_{t-1}$ \\
\hline 1 & 0.0121 \\
2 & $0.0171^{*}$ \\
3 & $0.0221 * * *$ \\
4 & $0.0272 * * *$ \\
5 & $0.0322 * * *$ \\
6 & $0.0372 * * *$ \\
7 & $0.0423 * * *$ \\
8 & $0.0473 * * *$ \\
9 & $0.0523 * * *$ \\
10 & $0.0574 * * *$ \\
\hline
\end{tabular}

Note: $* * * \mathrm{p}<0.01, * * \mathrm{p}<0.05, * \mathrm{p}<0.1$

The table shows the impact (elasticity) of $\log$ Buy Pat Count $t_{t-1}$ on Log Supp Pat Prod for buyer-supplier relationship durations ranging from 1 to 10 years.

Table 6: Main coefficients of robustness test regressions

\begin{tabular}{|c|c|c|c|c|}
\hline Specification & Description of Robustness Test & Buyer Patent Count & S.E. & $\mathrm{N}$ \\
\hline (1) & Fixed effects & $0.0212 * *$ & 0.105 & 706 \\
\hline (2) & Random effects & $0.0230 * * *$ & 0.082 & 706 \\
\hline (3) & Panel-Tobit random effects & $0.0231 * * *$ & 0.101 & 706 \\
\hline (4) & Without lag & 0.0158 & 0.138 & 1167 \\
\hline (5) & With lagged control variables & $0.0230 * *$ & 0.078 & 706 \\
\hline (6) & Subsample: dy ads with large size differences & $0.0176^{*}$ & 0.142 & 332 \\
\hline (7) & Subsample: dy ads with small size differences & 0.0213 & 0.108 & 374 \\
\hline$(8)$ & NB fixed effects count model & $0.000645 * * *$ & 0.085 & 514 \\
\hline (9) & Poisson fixed effects count model & $0.000525 * * *$ & 0.229 & 514 \\
\hline (10) & Fixed effects with buyer patent productivity & $0.229 * * *$ & 0.136 & 706 \\
\hline
\end{tabular}

Note: $* * * \mathrm{p}<0.01, * * \mathrm{p}<0.05, * \mathrm{p}<0.1$ 